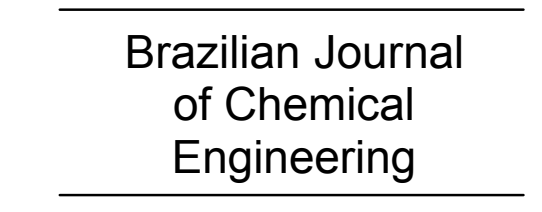

ISSN 0104-6632

Printed in Brazil

Vol. 19, No. 03, pp. 355 - 358, July - September 2002

\title{
THE DRYING OF SOLIDS IN A MODIFIED FLUIDIZED BED
}

\author{
M.C.B.Ambrosio ${ }^{1}$ and O.P.Taranto ${ }^{2}$ \\ ${ }^{1}$ Departamento de Termofluidodinâmica, FEQ, Universidade Estadual de Campinas, \\ Campinas - SP, Brazil. E-mail: miriam@feq.unicamp.br \\ ${ }^{2}$ Departamento de Termofluidodinâmica, FEQ, Universidade Estadual de Campinas, \\ Cx. P. 6066, CEP 13083-970, Campinas - SP, Brazil. \\ E-mail:val@feq.unicamp.br
}

(Received: December 10, 2001 ; Accepted: September 2, 2002)

\begin{abstract}
When fine and cohesive particles are the subject of study, fluid beds are of concern of due to the formation of channeling. This work presents a study that was carried out on the drying of fine particles, in this case a crystalline organic acid, in a mechanically stirred fluidized bed. The drying kinetics curves were determined by evaluating the influences of initial moisture content and temperature of the drying gas at the entrance of the bed. This study shows the suitability of the stirred fluidized bed for the drying of solids of low-quality fluidization.

Key words: fluidized bed, drying, particulate material.
\end{abstract}

\section{INTRODUCTION}

The drying process is an operation that aims at a reduction of the moisture content in most products, industrialized or not, to guarantee their preconservation in storage and transport (Keey, 1992). The process of fluidization with hot air is highly attractive for the drying of powders and wet granular materials. This technique has been used industrially and is currently quite common in the drying of coarse materials, pharmaceuticals and food products among other solids.

For storage purposes the moisture content of crystalline organic materials must fall within a commercially acceptable range so that the materials do not undergo any type of degradation or alterations in quality or appearance. To achieve the desired moisture content, the material must be dried; several types of commercial equipment are available for this purpose (Ambrosio, 1999). For particulate materials that have cohesive characteristics, the conventional fluidized bed has some restrictions on its use due to the formation of channels. Insertion of a stirring paddle in the fluidized bed to improve fluidization has been proposed.

Reed and Fenske (1955) and Brekken et al. (1970) studied the effects of mechanical agitation in the fluidization of solids, including group $\mathrm{C}$ powders, and concluded that paddles broke down channeling and particle agglomerates in the bed, which helped the movement of particulate material and improved fluidization throughout the bed.

In this work the drying of a crystalline organic acid with an initial moisture content of up to $30 \%$ and cohesive characteristics when wet was studied. The drying kinetics curves were determined in order to evaluate the influence of initial moisture content and gas temperature on final moisture content.

\section{MATERIAL AND METHODS}

\section{Material}

In this drying study, 2-hydroxybenzoic acid, which is a crystalline organic acid with cohesive 
characteristics when wet, was used. Its main characteristics are $\mathrm{T}_{\text {sublimation }}=76^{\circ} \mathrm{C}, \rho_{\mathrm{s}}=1.443 \mathrm{~g} / \mathrm{cm}^{3}$ and $\mathrm{d}_{\mathrm{p}}=80 \mu \mathrm{m}$ (average) (Kirk-Othmer, 1982; Ambrosio, 1999).

\section{Experimental Methods}

The experimental system that was used in the drying process has a stainless steel cylindrical bed with an internal diameter of $14.3 \mathrm{~cm}$ and a height of $70 \mathrm{~cm}$. The mechanical agitation system is an anchorshaped stirring paddle, also of stainless steel, located directly above the distributor. More details regarding the experimental equipment were presented in Ambrosio et al. (2000). In the study on drying of 2hydroxybenzoic acid, two different moisture contents were used, one around $10 \%$ and the other around $26 \%$; bed height was fixed at $7 \mathrm{~cm}$ and two drying air temperatures, $65^{\circ} \mathrm{C}$ and $85^{\circ} \mathrm{C}$, were chosen. During each experimental run, samples of solids were taken every five minutes in order to analyze the moisture content.

Carr's index and the Hausner ratio were measured using the Powder Characteristics Tester (model PTN, Hosokawa Microns). This analysis was used to determine the fluidity of the dry solid. Carr's index (Carr, 1965) was measured with the equipment, and the Hausner ratio was calculated by the ratio of tapped bulk density to aerated bulk density (Geldart et al., 1984).

\section{RESULTS AND DISCUSSION}

The experimental results obtained in the drying study for cohesive crystalline organic acid can be seen in Figures 1 and 2. In these illustrations it can be clearly observed that only the constant-rate drying period is represented in the drying curve under these processing conditions. During the constant-rate drying period, the solids temperature is very close to that of the wet bulb of the drying gas, so during this drying experiment $85^{\circ} \mathrm{C}$ could be used because solid particles did not reach sublimation temperature and therefore did not damage the crystals.

A decrease in drying time of approximately five minutes with a higher temperature for the drying gas $\left(85^{\circ} \mathrm{C}\right)$ can also be seen. This demonstrates saving of energy economy in the drying process without a negative affect on the final quality of the product, with the same range of final moisture content.

To evaluate the morphology of the dry crystals, photomicrographs (Figures 3 and 4) were taken for comparison of wet and dry materials. In Figure 4 it can be observed that the dry solid was needleshaped, showing that the equipment used did not damage the crystals, and the presence of fines was very small when compared with that in Figure 3, which could be caused by the dragging of fine particles during the drying experiments.

Table 1 shows the results of flowability and compressibility analysis for dry particulate material using the Powder Characteristics Tester. The Carr's index $\left(\mathrm{I}_{\text {carr }}=17.2\right)$ value in Table 1 , in accordance with Carr (1965), indicates that this powder is classified as free-flowing powder. In respect to the Hausner ratio, in accordance with Geldart et al. (1984), the solid had HR = 1.21, indicating group A characteristics and free-flow properties. Solid fluidity was analyzed because the behavior of the powder in handling and processing devices is related to the properties of the particles. The results presented in Table 1 show that the stirred fluidized bed used in the drying process yields solids with good flowability characteristics, facilitating subsequent operation of the production process.

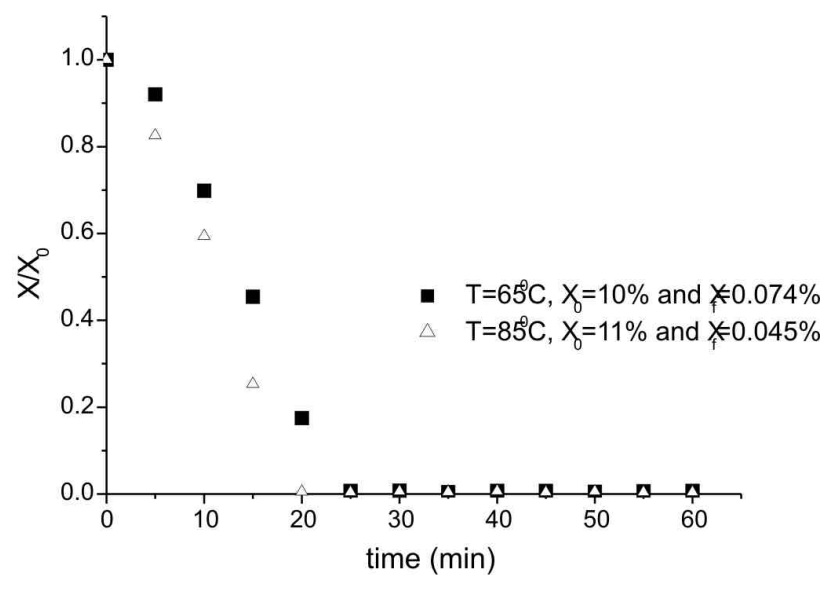

Figure 1: Drying curves with $\mathrm{X}_{0}$ around $10 \%$. 


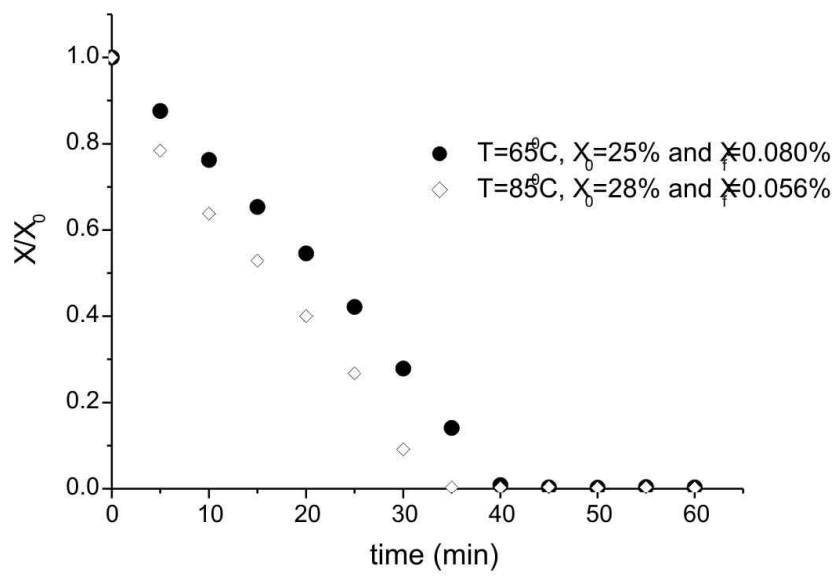

Figure 2: Drying curves with $\mathrm{X}_{0}$ around $26 \%$.

Table 1: Results obtained in the Powder Characteristics Tester

\begin{tabular}{|c|c|}
\hline Properties & Dry material \\
\hline$\rho_{\mathrm{b}}\left(\mathrm{g} / \mathrm{cm}^{3}\right)$ & 0.558 \\
\hline$\rho_{\text {tap }}\left(\mathrm{g} / \mathrm{cm}^{3}\right)$ & 0.674 \\
\hline Carr's index (\%) & 17.2 \\
\hline Hausner ratio & 1.21 \\
\hline
\end{tabular}

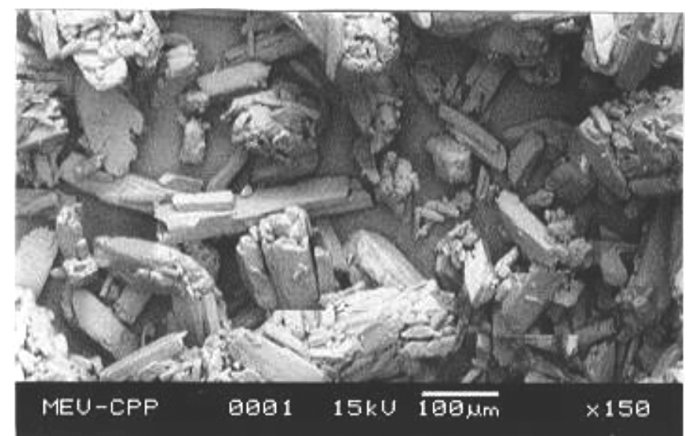

Figure 3: Wet material, 150x.

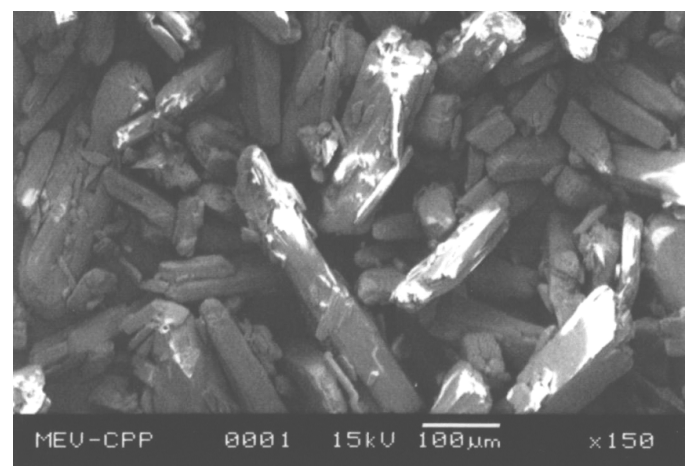

Figure 4: Dry material, 150x. 


\section{CONCLUSIONS}

In this study it can be concluded that agitation allowed fluidization of solids with cohesive characteristics, which is not likely to occur in the conventional fluidized bed. Agitation broke the channeling in the bed, decreasing the resistance of particles; is provided a quality fluidization and uniformly dried material with a final moisture content below 2,000ppm. This work showed that the dried particles produced in this equipment had better fluidity, which could facilitate the continuity of industrial processing, handling, transport and storage.

\section{ACKNOWLEDGMENT}

The authors would like to acknowledge the financial support received from FAPESP.

\section{NOMENCLATURE}

$\mathrm{d}_{\mathrm{p}} \quad$ particle diameter $(\mu \mathrm{m})$

$\mathrm{t} \quad$ time (min)

$\mathrm{T} \quad$ drying gas temperature $\left({ }^{\circ} \mathrm{C}\right)$

$\mathrm{T}_{\text {sublimation }}$ sublimation temperature of material

$\left({ }^{\circ} \mathrm{C}\right)$

$\mathrm{X}_{0} \quad$ initial moisture content $(\mathrm{kg} / \mathrm{kg})$

$\mathrm{X}_{\mathrm{f}} \quad$ final moisture content $(\mathrm{kg} / \mathrm{kg})$

$\rho_{\mathrm{b}} \quad$ aerated bulk density $\left(\mathrm{g} / \mathrm{cm}^{3}\right)$

$\rho_{\mathrm{s}} \quad$ density of solids $\left(\mathrm{g} / \mathrm{cm}^{3}\right)$ $\rho_{\text {tap }} \quad$ tapped bulk density $\left(\mathrm{g} / \mathrm{cm}^{3}\right)$

\section{REFERENCES}

Ambrosio, M.C.B., Secagem de particulado coesivo em secador de leito fluidizado agitado, Campinas: UNICAMP - FEQ, Master's thesis, 133p. (1999). Ambrosio, M.C.B., Taranto O.P., Leistner, M., Drying a Cohesive Particulate Material in Mechanically Stirred Fluidized Bed, Proceedings of the $12^{\text {th }}$ International Drying Symposium IDS2000, Elsevier Science, Amsterdam, Paper No. 386 (2000).

Brekken, R.A., Lancaster, E.B., Wheelock, T.D., Fluidization of Flour in a Stirred Aerated Bed: Part I. General Fluidization Characteristics, Chemical Engineering Progress Symposium Series, v. 66, n. 101, pp.81-90 (1970).

Carr, R.L., Evaluating Flow Properties of Solids, Chemical Engineering, 18, pp. 163-168 (1965).

Geldart, D., Harnby, N., Wing, A.C., Fluidization of Cohesive Powders, Powder Technology, 37, pp. 25-37 (1984).

Keey, R.B., Drying of Loose and Particulate Materials, New York: Hemisphere Publ., pp. 2932 (1992).

Kirk-Othmer, Encyclopedia of Chemical Technology - vol. 20, Toronto: John Wiley \& Sons, $3^{\text {rd }}$ edition, pp. $501-510$ (1982).

Reed, T.M., Fenske, R., Effects of Agitation on Gas Fluidization of Solids, Engineering, Design, and Process Development, v. 47, n. 2, pp. 275-282 (1955). 